\title{
Cosmopolitan Modes of Governance of Religious Diversity across Europe
}

\author{
Anne Koch \\ Research Professor, Private University of Education of the Diocese of Linz, \\ Linz, Austria \\ anne.koch@ph-linz.at
}

\begin{abstract}
From the various contingent cases of interreligious dialogue (IRD) across European countries presented at the conference, a systematic cross-regional comparison and system-theory informed analysis is suggested from a cultural study of religion understanding. Along the coordinates of system integration, social integration and cosmopolitanism (as developed in political sciences by U. Beck, E. Grande, N. Sznaider) an interpretation of the specific way of governance is proposed and delineated from other explanations like IRD as part of a neoliberal regime or a type of secularism. The paper concludes how IRD initiatives, besides other effects, form cosmopolitan values of open coordination, risk management, and mutual recognition and by this contribute to their institutionalization. Cosmopolitanism is favoured as policy paradigm for religious diversity as it allows for multi-level communication in-between global localities, changes perspectives with marginalized and draws conclusions from that for regulating diversity without regulating individuals.
\end{abstract}

\section{Keywords}

cosmopolitanism - inter faith - religious diversity - governance of religious diversity religion in Europe - interreligious dialogue 


\section{Introduction}

This theory-oriented paper follows a double aim: First, from the various contingent cases of interreligious dialogue (IRD) across European countries presented at the conference, ${ }^{1}$ this paper retrieves relevant categories in which scholars describe and analyze IRD and second, it proposes systematic lines along which governance in this field may be described. It seems as though a new subfield of 'inter faith governance' (IFG) emerges that provides empirical evidence through social scientific research and ethnographic case studies and theory building recently especially from studies in governmentality ${ }^{2}$ as started by late Michel Foucault. ${ }^{3}$ This approach diverges vastly from an emic, intercultural-theological or engaged perspective, and instead tries to understand territory-specific ways of religious pluralization, secularization, ${ }^{4}$ and the neoliberal regime. In Denmark, for example, work on IRD just took this as a case of 'organized encounter' besides and in comparison with other forms and societal 'spaces of transformation. ${ }^{5}$ This is quite a new perspective. On the grounds of rich material on IRD in Europe, a systematic cross-regional comparison and system-theory informed analysis is suggested from a culturalstudy-of-religion understanding. It combines governance studies with cosmopolitanism as developed in political sciences only recently and adopts it for our topic of religious diversity regulation.

\section{The Potential of the Inter Faith Governance Perspective}

\subsection{Network Governance, System Integration, and Social Integration}

In a first step, the respective disciplinary and theoretical analytic perspective on IFG will be explicated. A key thesis to IFG is that these activities are part of the federal, communal or state's regulation of religious plurality. Often, even a "religious-secular competition" is vital in the field. ${ }^{6}$ Like this, state, communal,

1 The present issue of the 'Journal for Religion and Transformation in Contemporary Societies (JRAT)' is based upon contributions to the conference 'Interreligious Dialogue in Context. A European Comparison (IRD-Con)' that took place between October 17 and 19, 2019, in Vienna, Austria.

2 For example Breda Gray, Alexander K. Nagel, Maria del Mar Griera, Marian Burchardt.

3 Foucault, Biopolitics, Vol. II on Neoliberalism.

4 Lehmann, Interreligious Dialogue - a Response to Processes of Secularization.

5 Galal, Between Representation and Subjectivity.

6 Stolz/Könemann, Religious-Secular Competition, pp. 11-50, who hold a rational choice approach instead of governance studies. 
and town governance of religious organizations are the first concepts to expound. Besides a bottom-down governance, the state may initiate grassroots or assign intermediaries to organise encounter. The German Islam Conferences might serve as an example of a state-stakeholder partnership. The German state invites and negotiates with various Muslim organizations over questions of legal constitution, financing and all sorts of questions on Muslim everyday life in Germany. Another way is represented through bottom-up governance that may be initiated by programs that support the production of specific public goods where organizations will apply, or that emerges as activist movement ${ }^{7}$ according to dynamics of its own, or global, awareness like in cosmopolitanism. On the meso-level, urban authorities ${ }^{8}$ or federal states enter the scene to interact with interfaith partners especially when religion is a cantonal affair as in Switzerland. ${ }^{9}$ Sometimes the partners in this private-public partnership are intermediaries like interfaith organizations, but more often religious corporate actors. For religious organisations, IRD might be an opportunity to become more visible in public than they would be as single actors, if we think of religious joint ventures like opening ceremonies, intercultural festivities, cultural festivities. ${ }^{10}$ So, these religious organizations would lose their gatekeeper function when not engaging in IRD. Furthermore, a weak state might push religious organizations to engage in IRD especially in a post-conflict society like in Bosnia. ${ }^{11}$

A further mode of governance is through multilevel and pluricentric networks. As multilevel and pluricentric, they bind together religious leaders and/ or community-based initiatives, religious organizations from the local to the national or transnational level, private, public and state actors. They may gather around a variety of topics ranging from 'peace building' to feminism, ecology, reconciliation, spiritual exchange or social cohesion. Tuomas Martikainen has shown how the two interests in welfare/social work and inter-religious pacification are performed through multilevel and pluricentric network governance by which he understands alliances of interdependent agents for a "public purpose". 12 These new forms of neoliberal and managerial governance put new actors onto the stage in being less hierarchical and regulating in a myriad of ways. Through these networks, alternative forces step aside the Westphalian

7 Fahy/Bock, Interfaith and Social Movement.

8 Nagel, Empowerment or Oligarchisation.

9 Schmid, Interreligious Dialogues in Switzerland.

10 Kuppinger's ethnography on a suburb of the German town of Stuttgart convincingly demonstrates this rationale of IRD, Faithfully Urban.

11 Zifonun/Zakisa, Religiöse Vielfalt; Ilić, Looking Through a Veil.

12 Martikainen, Multilevel. 
system, and put more rigour to religious institutions, the secular-religion competition, and transgovernmental alliances. The advantages of this modality of governing are manifold: In networks, decision-making is performed by negotiation. A high flexibility is acquired through this way of consensus building. Then, through the interdependent pluricentric actors, detailed information on local situations is available that helps to successfully and efficiently implement appropriate policies in concrete places. Compliance is achieved via trust and political obligation. Trust is a stabilizing factor because of the actors' acquaintance or the reputation of groups. Interestingly enough, this network governance is expected to lead over time to self-regulation. This reveals premises from system theory and cybernetic models within this governance model.

Stabilising activities is what states hope for when supporting or initiating interfaith forums. This should legitimate the mentioned public purpose. To better understand this aim of societal stability, it is helpful to introduce two more analytical coordinates that differentiate between system integration and social integration. ${ }^{13}$ System integration addresses the cohesion of parts and groups within society as a whole. It is the solidarity of a society, whereas social integration means the opportunities for individuals to participate at societal affairs. It is the way that individuals have a place within societies, have a word to say, may be part of political processes. The case studies from European countries single out several options of system integration and social integration and finely deploy the alternating conditions within the country histories. We can resume some cases of system and social integration that interact in multiple ways with further contextual historical factors.

The governance of plurality on a system integrative level may be performed through:

- A (new) religiously encoded overarching narrative (e.g. nationalism in Bosnia-Herzegovina ${ }^{14}$ ) or narratives and 'myths' of opponents (of religious terrorism, historical events) that bind together

- State-church separation offering legal and financial frameworks for plural religious organisations and non-dominant religions

- State supporting welfare and social work (e.g. migration work)

- Religious organizations, especially churches that scale down to face-to-face encounters (Galal on Denmark's "theoretical individualism"15) and install divisions with special staff for IRD

13 Following Esser, Integration und ethnische Schichtung.

14 Alibašić, History of Inter-Religious Dialogue in Bosnia and Herzegovina.

15 Galal, Between Representation and Subjectivity. 
- People and dominant church merge, so that one can talk of a culturalization of a specific religion such as, for instance, Christianity or Islam become 'naturalized' as mainstream value system. A background for this can be a high score of secularism accompanied by expectations of vicarious religion (e.g. Denmark, $\mathrm{GB}^{16}$ )

- Bodies of interest/umbrella organizations at national level like the Swedish Interfaith Council. This development of founding cooperative bodies is particularly strengthened when state or communal funding for inter faith work is an incentive ${ }^{17}$

On the level of social integration, we might find that religion plays a role in the form of

- Religious plural pragmatism of lived religion

- Conflict mediated integration between religious neighbourhoods

- Privatized and individualized religion, withdrawal from public sphere

- Grassroots initiatives with a low, temporary or no degree of institutionalization

A driver to these new forms of governance is that state-church governance is judged "an increasingly outdated model",18 a historical development that has potentially opposite consequences:

The separation of church from state in both Norway and Sweden emphasises that no religious institution per se has a privileged position with respect to the state, which, again, strengthens the state's need for direct links to all faith communities. In this way, the religious umbrella organisations come to take up a position that is reinforced by the separation of church and state. ${ }^{19}$

Contrastingly, in Denmark the state-church-separation still privileges the dominant Protestant Church, but deems religion in general a private issue with no administrative or financial support for the many registered religious associations. ${ }^{20}$

Concerning state governance, Lise Paulsen Galal, Lund L. Liebmann and Magdalena Nordin parallel the general financial and administrative support of religious communities with that of special interfaith initiatives in the Nordic

16 Prideaux, Legitimising Religion in Public.

17 Galal/Liebmann/Nordin, Routes and Relations, p. 339.

18 Martikainen, Multilevel, p. 13 .

19 Galal/Liebmann/Nordin, Routes and Relations, p. 335.

20 Galal/Liebmann/Nordin, Routes and Relations, p. 337. 
countries and characterize it as 'top-down' governance often using the same models as ecumenical movements. ${ }^{21}$ An alternative to top-down governance would be to leave IRD to the religious group's own devices with only grassroots initiatives as a consequence. ${ }^{22}$ In this last case, majority churches might play a stronger role due to their resources as intermediaries of IRD. The named modes of system integration rely on a heated debate of integration in postimmigration societies. ${ }^{23}$

\subsection{European Cosmopolitanism as a Key to Analyze Norms}

Along with the governance dynamics detailed above we will employ a further coordinate, that of cosmopolitanism, through which we will be able to better evaluate, on the one hand, the normativity within the highly complex configuration of IRD and, on the other hand, a social self-organizing force as actor. Cosmopolitanism, chosen here, is a relatively newly refined perspective in social and political sciences trailing behind theories of world polity, world society and world system. ${ }^{24}$ 'Methodological nationalism' is substituted by a European "methodological" or "realistic cosmopolitanism" that empirically examines border crossings beyond the nation state and beyond dualisms of foreign/familiar, trans/national, we might want to add: religious/secular coming together with homo/heterosexual ${ }^{25}$ and other highly normative categories. ${ }^{26}$ A first normativity comes in through Ulrich Beck's findings of a world risk society. Following these considerations, Natan Sznaider and Beck formulate a 'cosmopolitan momentum' at the beginning of the 21st century. The reason is an intensified interdependence of actors in a globalized and digitalized world, and especially due to four crises that sharpen the cosmopolitan awareness:

21 Galal/Liebmann/Nordin, Routes and Relations, pp. 337 et seq.

$22 \mathrm{Galal} /$ Liebmann/Nordin, Routes and Relations, pp. 337 et seq.

23 On several options for integration i.e. assimilation, individualist-integration, multiculturalism, cosmopolitanism; see overview: Modood, Post-Immigration, p. 6, even though his concept of multiculturalism equals more 'cosmopolitanism' as propagated here, see e.g. his request for a feeling of belonging to the whole, p. 14 .

24 See Beck/Grande, Cosmopolitanism, pp. 70-72, on the history of the concept and vis-à-vis similar theory-building, for its distinction from nationalism, particularism, and universalism, and its successful dealing with otherness and the reconciliation of self-interested agents with world citizens - opposing neoliberal models of society according to global markets with only self-interested actors. Beyond a 'banal cosmopolitanism' (Beck/ Grande, Cosmopolitanism, p. 72) of ethno food and hybrid everyday culture of clothing or music styles, they develop a 'reflective and institutionalised cosmopolitanism'. In distinction to transnationalism, in the cosmopolitan framework the nation state is no relevant reference point for this new kind of community building in IRD.

25 Joy, Gender.

26 Beck/Sznaider, Unpacking Cosmopolitanism. 
the ecological crisis, a series of financial crises (global and European), terrorist risks in the middle of European towns (London, Madrid, Paris etc.), and moral risks. ${ }^{27}$ On the last two axes, religion again reappears massively as a collective actor, threat, just as well as a vision. In light of threats and risks, a pressure to co-operate arises. Interestingly enough, cultures of similar risk perception emerge across countries and form communities of like-minded moral worlds. Towards this, we have to see IRD initiatives as "interfaith movements" that engage in reconciliation, social cohesion, social justice, poverty alleviation and climate protection "moving into the mainstream" worldwide. ${ }^{28}$

Equally, IRD is not understandable without considering 'cosmopolitan awareness' and the effects it has on religious activities and networks - one thinks of human rights ${ }^{29}$ or charity ${ }^{30}$ activism: "What is new is not forced mixing but global awareness of it, its self-conscious political affirmation, its reflection and recognition before a global public via the mass media, in the news and in the global social movements of blacks, women and minorities". ${ }^{31}$ Self-reflexive actors in IRD intentionally employ social, social activist, social work and therapeutic technologies.

Beck and Sznaider distinguish "cosmopolitanism as a set of normative principles and (really existing) cosmopolitanization". ${ }^{32}$ The normative set contains a positive evaluation of mobility and efficiency, global solidarity, of the implementation of social technologies to improve collaboration and the governance of happiness of societies through organizations that are stakeholders of the state. "Real cosmopolitanism", by contrast, is more ambivalent and somehow broken: exploitation of nature, exclusion of illegal persons and poor, economic colonizing and land dispossession through global corporations. It is often unintended and only institutionalized over time. Symbols and rituals are important to adapt to social identities: "The more such rituals contribute to individuals' personal sense of conviction, the larger the critical mass available to be mobilized in cosmopolitan reform movements". ${ }^{33}$ Hansjörg Schmid gives an impressive example of an interfaith ritual in St. Gallen, Switzerland, that

27 This last one due to a spread of human rights discourses, Beck/Sznaider, Unpacking Cosmopolitanism, p. 11. See also Lehmann, Religious NGOs.

28 Fahy/Bock, Interfaith and Social Movement.

29 Lehmann, Religious NGOs, amply discusses in the contest of human rights on terminology and distinguishes relevant discourses on 'transnational religion', 'Islamism' etc. and who the actors are.

30 For yoga initiatives as new actors at charity markets in the tradition of cosmopolitan Band Aid, see Koch, Competitive Charity.

31 Beck/Sznaider, Unpacking Cosmopolitanism, p. 10.

32 Beck/Sznaider, Unpacking Cosmopolitanism, p. 10.

33 Beck/Sznaider, Unpacking Cosmopolitanism, p. 10. 
unites - and makes visible and audible - religious diversity in clothes and music. ${ }^{34}$

IRD communities are nostalgic in the sense that they form a community of people of good will beyond national, ethnic and other belongings. Especially in the field of IRD peace building, we find a majority of cosmopolitan institutional forms like Religions for Peace or Pax Romana. ${ }^{35}$ They rely on cosmopolitan religious traditions with their respective ethos, mentalities, and social milieus. These go beyond the theoretical issue of the state and cover an entity of a broader cultural belonging and morals that is based in moral emotions - as we learn from research in moral psychology. Beside these, some case study examples also witness more pragmatic forms of cooperation for respective goals.

Having said all this, one should not be tempted - especially with a view to cosmopolitan IRD - by a normative agenda that idealizes mutual understanding, harmony, same values, and anti-hegemonism. Empirical work on a 'real' and already existing interdependency of IRD activities is more instructing in order to evaluate options for in/stability. This still is a lacuna.

It still is the state and religious organization but also complex networks who initiate IRD or exert IFG. This comes along with all the problems of 'legitimate' or 'accepted' representation, especially in the Muslim case. The problem is not so much - as often said in the discourse on Muslim organizations - that we have so many groups, - they are not more than the Christian groups, - but that they only appeared recently, which means they are historically 'younger' and the field is still organizing itself, negotiating shares with other stakeholders and the legal system needs to adapt to this situation. Another problem is governance through representation that prevails in IRD instead of governance through participation. Cosmopolitanism suggests a difference-friendly integration that keeps a certain degree of diversity on a common ground. ${ }^{36}$ Below we will continue with the topic of the 'who' by discussing several regimes of governance as overarching formations behind the named actors.

The 'why' of IRD initiatives' occurrence is answered with a view to world risk societies and the pressure to co-operate: scenarios of threat and risk appear with the already iconic $9 / 11$, the post-Soviet dissolution of political constructs and post-conflict societies. A further important cosmopolitan influence 
for Europe is the more general 're-emergence' or 'new visibility' of religion in public space in a secular framework. Throughout history, it has been a vital task for societies to regulate and adjust religious plurality. In modern times some socio-cultural contexts like societal differentiation come into play that exert new effects, whereas, proponents like the secular, non-religion and 'civil' spheres, that are regularly opposed to the religious, possess a much longer history. Today, it is exactly the theological voices in the discourse on post-secular societies that prominently bring in a role for religions again.

This leads us to the question about how 'successfully' IRD goals are realized and how the effect of IRD may be measured. This question can be put two ways: One might ask how the emic goals like peace, social cohesion or learning about each other's religion are reached ${ }^{37}$ or one asks which impact these practices have regardless the emic ascription and aspiration on societal transformation. Marian Burchardt argues "while secularism is surely an important mode of governmentality of religion, religious diversity has itself become a form of governmentality that is not necessarily subordinated to secularism“38 and even names a "religious power itself" ${ }^{39}$ Like this, IRD looks quite effective. Furthermore, Burchardt subordinates all activities in this field under the overall neoliberal regime from constructing diversity to regulating religion. This is a strong thesis as it puts neoliberal features above other explanations of IRD like, for example, moral understandings of IRD (see Beck and Sznaider above) or functional understandings - for instance, that stakeholders receive more public visibility through interreligious performance and like that keep vicarious reputation. This is not to deny that the 'neoliberal regime' or neoliberalism as a cultural ideology have a severe impact on current societies. A very good exemplary governance analysis of the Irish Church's application for public funding to take part in migration work by Breda Gray shows how strongly religious organizations under neoliberal governance change in becoming civil society agents: they employ social workers, apply for public funding, treat 'cases', and invoice local communities. ${ }^{40}$ The consequences are an altered portfolio of human capital, financial dependence, different communicational forms,

37 With a view to the contributions on IRD in European countries, the question about particularities of confessional cultures arose with the impression of more universalist catholic histories where initiatives are striving for peace worldwide and the later protestant countries whose main goal it was to limit religious wars and to keep their own territory peaceful (e.g. Galal on Denmark).

38 Burchardt, Diversity as Neoliberal Governmentality, p. 181.

39 Burchardt, Diversity as Neoliberal Governmentality, p. 181.

40 Gray, Catholic Church. In this civil society activism of migrant integration in Ireland, she examines, the neoliberal effects are naturally stronger than in multi faith activities that are looser in organizational degree. 
audits, and competitors from other secular and religious organizations. Besides neoliberalization, we find a strong practical reasoning and individual ad hoc solutions responding to concrete challenges, that lead - to a certain degree - to a more pragmatic instrumentalization of inter faith interventions. ${ }^{41}$

Critically one has to remark that the critic of the 'neoliberal age' needs to take a much closer look from the economics of religion perspective and distinguish where market forces change institutional forms and practices, and if, at all, activities are performed at competitive partial markets or to a greater degree at highly regulated markets, heavily subsidized markets or non-profit markets, because in these the intentionality of political decisions is more vigorous than market forces.

Nevertheless, the answer regarding effectiveness remains rather unsatisfyingly as one can only point to rather vague changes in mentality which is an important subject of social psychology. At least, as important as neoliberalizing forces, are further dynamics like individualization that put identity building into new challenges under conditions of pluralized options. Towards this background the human rights movement makes more sense as a response to a violation of individuals' rights somewhere in the world that 'European' subjects experience as if their own individualism was threatened. So, one will have to consider, if the movement is really about human rights or one's own identity markers. This, as well, leads to the effect that in so called reflexive second modernity "issues of global concern are becoming part of people's moral lifeworlds" in a way that the cosmopolitan outlook is always internalized regardless of whether people adhere to it or oppose it. ${ }^{42}$ There lies a tension between the strong individual interest and more communitarian ideals and imagined communities. Which one comes first - in case religious organizations in IRD have to take a decision, let us say about recognizing the otherness of a community? Imagine recurrent court cases during the last years like the circumcision of boys or whole-body swimsuits for girls. The heated opposition was seen between the right of individuals on the one hand and the right of groups on the other hand. With a view to the governance of diversity in Europe, a difference-friendly integration is suggested following the principle of mutual recognition, ${ }^{43}$ that means that, first, practices only need to be compatible under the shared European requirements, but not identical, and second, the different regulations need be recognized between the partners. ${ }^{44}$

\footnotetext{
41 Lindner/Lehmann, Impulse, p. 146; Nagel, Empowerment or Oligarchisation, pp. 116 et seq.

42 Beck/Sznaider, Unpacking Cosmopolitanism, p. 13.

43 Beck/Grande, Cosmoplitanism, pp. 74 et seq.

44 Beck/Grande, Cosmoplitanism, p. 74.
} 
Worth discussing is the considerably political self-instrumentalization of IRD for social cohesion within a given society. The emic categories of 'cohesion', 'peace building', as well as the ecology movement are nostalgic in the sense that they found strong emotional communities. These bridge heterogenous interests and enduring class differences as if the entire younger generation would be united in protecting the environment and changing its life accordingly. With a risk and threat scenario in the background, this felt cosmopolitanism institutionalizes cosmopolitan agreements on the respective goals of IRD, - that leads us back to the evaluation of the effects of IRD interventions. In the end, IRD appears as discursive practices of particular community building whose particularity is not per se 'religious' but more ambiguous. The ambiguity lies within the possibilities of, on the one hand, reifying in/exclusions in reproducing entities that come along with each other or not (the 'big five' of 'world religions', 'Abrahamitic family', 'European Islam') or of reifying the religious against the secular. Especially Protestant actors in a case study from a German town feel unease being political "through the state" instead of vis-à-vis. ${ }^{45}$ Otherwise, IRD might be a performance of reflective actors in second modernity that build up moral life worlds from religious traditions and institutionalize a network across other political forces. These actors know very well to behave strategically and pragmatically towards the public expectations and authorities and to master a backstage where they might sit with 'not welcome' religious minorities for informal contact, - a "profanisation of interreligious dialogue due to its utilisation as a governance instrument".46 A major push factor for secularization within IRD is the employment of social technologies. At the beginning stands a problematization of going wrong, followed by considerations on how to obtain transformation, to social technologies and then, a purpose that is the ordering of chaos. ${ }^{47}$ And this then is not so different from other scholarly experts' opinions on how to improve conviviality that leads us to the problem of the third question to sharply distinguish the

45 Nagel, Empowerment or Oligarchisation, p. 116.

46 Nagel, Empowerment or Oligarchisation, p. 117. As co-founder in 2007 and volunteer in an interfaith association in Munich/Gemany until 2018, I gathered experiences with diverse religious, multifaith as well as urban stakeholders. With a very educated middle-class mind-set we offered certificates of 'interreligious dialogue pilots' understood as facilitators of multireligious-secular interventions in kindergarden, school, university, communal conflicts, communal authorities and in the public. Contents of this education over two years encompassed eight full days and included basic knowledge of interreligious learning and peacebuilding, forms of interfaith celebrations/concerts, conflict mediation, and a lived encounter with diverse religious groups. Now this curriculum is part of an ecumenical inter faith education of the Churches in Bavaria. 
IRD discourses from academic discourses. As reflexivity and an awareness of employing tools for certain goals is a common ground, academia is already entangled into the field.

In an emic use, 'secularization' is a recurrent reference point for religious agents to ally or/and create a threat. In an etic use of 'secularism', some scholars refer to a regime that might employ or promote IRD to realize several aims. The antagonistic relation of academic and activist discourse is part of the 'regime of secularism'. Secularism as political agenda and major order may intensify religious conflicts and inter faith constellations of disagreement as it does not take into account the pluricentric and multilevel networks that heavily rely on religious actors. ${ }^{48}$ The same critic is proposed towards the regime of multiculturalism that is said to serve the flow of human capital in the interest of a global finance market capitalism and only therefore idealizes the plural cultures as 'multicultural' neglecting to really share resources. ${ }^{49}$ In any case, today's immigrant societies also gain an interfaith awareness through the institutionalization and self-organization of religious immigrant communities ${ }^{50}$ and not only through secularization. The players of IRD are in vivid use for the governance interests of towns, nation states as well as of bodies of the European Union, for religious pluralization, to reach out for marginalized groups, and recently also with a view to the rearrangement of interreligious education. ${ }^{51}$ When looking

48 Mahmood calls this state governance towards religions "political secularism", Religious Reason. With a view to the discrimination of Egyptian Coptic Christians, she describes secularism as a normative order that arranges what religion is and ought to be. See also Schuh/Burchardt/Wohlrab-Sahr, Contested Secularities for the Netherlands where the 'immanent frame' are universalist civil liberties to which religion is subordinated.

49 For instance, Burchardt, Diversity as Neoliberal Governmentality, referring to Slavoj Zizek, Zygmunt Bauman and others, positively: Beck/Sznaider, Unpacking Cosmopolitanism, p. 10; Modood, Post-Immigration.

50 Nagel, Enacting Diversity, p. 111, interestingly enough, here Nagel choses symbolic interactionism of Erving Goffmann to modulate boundary work within inter-faith activities.

$5^{1}$ See the engagement of scholars from study of religion in the only working group of the European Association of the Study of Religion (EASR) on "Religion in Public Education" (http://www.easr.eu/) led by Wanda Alberts and Tim Jensen, that follows a rather normative agenda insofar as it aims at "a specific 'RS-based RE didactics and school subject', i.e. a particular form of education about religion/s based on the academic study of religions, independent from any kind of promotion of religion or support of religious institutions or communities." This competes with suggestions from the side of theology and religious education arguing for a multireligious cooperative education, see e.g. Schambeck, Plea. In her expert plea at the European Parliament she advocates a rational public approach towards religion against its privatization and for the continuance or integration of (multi) religious education within public education. Reminding of Pisa's goals of European Education she argues that religion's concern with a "sense of humanity" and ultimate concerns should find "spaces" in schools. She puts forth three competencies on the base 
at this vivid debate, the conference's approach on national examples needs to be followed up with considerations on European governance of religious diversity beyond national power-orientation. In this line, cosmopolitanism might offer a fuller approach than governmentality. ${ }^{52}$

The contributions of the conference ${ }^{53}$ fill a lacuna of empirical research on interreligious dialogue initiatives across European countries and the kind of governance and function they take thereby. With a view to IRD, we asked for the premises and consequences of this regime of diversity. We rejected attempts that too easily subsume goals of IRD like peace building or social cohesion under the neoliberal regime of multiculturalism. Instead, we brought up ideas from world risk society on cosmopolitanism as a group formation responding to similar risk and threat perceptions. IRD may be considered as a type of these particular group formations, when governance is exerted onto individuals, their freedom and liberality, that found their 'identity' - and through which they become steerable via membership in groups of allegiance. The perception of risk and threat, in which these initiatives converge, institutionalizes a particular outlook on the world and, by this, becomes a reality of its own. So, cosmopolitan allegiances of same risk perception emerge through IRD work and may compete with alternative understandings of diversity. It also fosters the process of the de-privatization of world view attitudes which is a sensitive topic. Within multiple modernity, regimes multiply: it is not only 'religious pluralism governance' but also 'neoliberal regimes' and modes of 'secularism'. When multi- and inter-faith work forms part of a state-market-social governance, it can be subsumed to 'secularities'.

There remains a lot of empirical research to carry out with a view to the concrete ways of regulation through IRD networks on more informal levels - how much is planned and laid down in agendas of collaboration and how much of it is accidental? - and with a view to the influence of the market (welfare, social work, charity markets). To answer these questions would be necessary to

of which interaction with other worldviews might be successful: an understanding of the multidimensionality, reflexiveness, and critical self-examination. the acronym for REligious Studies Infrastructure: tooLs, Expert, conNections and CEnters in Europe, www.resilience-ri.eu.

53 The conference 'Interreligious Dialogue in Context. A European Comparison (IRD-Con)' took place between October 17 and 19, 2019, in Vienna, Austria. 
determine the manner of governance exerted in these activities. The perspective from governmentality studies describes routinization or profanization in IRD, but these have already been treated vastly within secularization and social differentiation theory. What is new, on the other hand, from cosmopolitan theory is, first, its capacity to explain horizontal communication between states on multiple levels. This is especially applicable to religious global organizations that produce public goods among other types of goods across - 'horizontal' to - national borders, as European paths of pilgrimages, peace initiatives, the cosmopolitan self-understandings of religious conviviality of umma, ${ }^{54}$ ecclesia, dharma. Second, its focus on self-reflexivity and detachment is precious, meaning the capacity of taking the perspective of the marginalized and precarious. This is an especially important element from social justice cosmopolitanism. And third, 'cultural cosmopolitanism' has the adaptative capacity to mediate between ways of life and worldviews, and is not putting religion into a special role nor is feeling the urge to devalue it.

\section{Biography}

Anne Koch is Research Professor for Interreligiosity and Study of Religion at Private University of Education, Linz, Austria. Her main areas of research are religious-secular pluralism, economics of religion and aesthetics of religion/ embodied cognition. She applies models especially from placebo research, cognitive sciences and new institutional economics to contemporary religion. Her main focus is on contemporary religion in Europe - informal, formal and secularist - and on global religious discourses and cosmopolitan spirituality. She is interested in interdisciplinary studies on the efficacy of spiritual healing and in how religion is changing in terms of commodification and consumer culture. She has conducted a number of fieldwork projects on healing in diverse traditions and studied global urban yoga for two years in Japan. She is co-editor of the Journal of Religion in Europe and board member of several book series and journals. Recent publications: (with K. Wilkens, eds.) The Bloomsbury Handbook of The Cultural and Cognitive Aesthetics of Religion; (ed.) Religionsästhetik (special issue Verkündigung und Forschung); (ed.) Aesthetics of Civil Religion (special issue Journal of Religion in Europe); (with C. Auffarth, A. Grieser, eds.) Religion in Culture - Culture in Religion: Burkhard Gladigow's Contribution to Shifting Paradigms in the Study of Religion (Tuebingen UP open 
access); Some important conceptual lines of discourse theories in cultural studies of religion. In:J.Johnston, K. von Stuckrad (eds.), Religion and Discourse Research: Disciplinary Use and Interdisciplinary Dialogues. Homepage: https:// annekoch.academia.edu.

\section{Bibliography}

Alibašić, Ahmet: History of Inter-Religious Dialogue in Bosnia and Herzegovina: From Force-Feeding to Sustainability?, in:JRAT 6 (2/2020), pp.

Beck, Ulrich/Sznaider, Natan: Unpacking Cosmopolitanism for the Social Sciences: A Research Agenda, in: The British Journal of Sociology 57 (1/2006), pp. 1-23.

Beck, Ulrich/Grande, Edgar: Cosmopolitanism. Europe's Way out of the Crisis, in: European Journal of Social Theory 10 (1/2007), pp. 67-85.

Burchardt, Marian: Diversity as Neoliberal Governmentality: Towards a New Sociological Genealogy of Religion, in: Social Compass 64 (2/2017), pp. 180-193.

Carl, Morris: Islamic Cosmopolitanism: Muslim Minorities and Religious Pluralism in North America and Europe, in: John Fahy/Jan-Jonathan Bock/Samuel S. Everett (eds.): Emergent Religious Pluralisms. Bastingstoke: Palgrave Macmillian, 2019, pp. 21-48.

Esser, Hartmut: Integration und ethnische Schichtung. Arbeitspapiere 40, Mannheim: Mannheimer Zentrum für Europäische Sozialforschung 2001, http://edoc.vifapol. de/opus/volltexte/2014/5134/pdf/wp_40.pdf (date of last access: 01.02.2020).

European Association of the Study of Religion (EASR): "Religion in Public Education", http://www.easr.eu/easr-working-groups/ (date of last access: 17.09.2020).

European Union research programme Horizon 2020 Resilience, acronym for REligious Studies Infrastructure: tooLs, Expert, conNections and CEnters in Europe, www. resilience-ri.eu (date of last access: 16.12.2019).

Fahy, John/Bock, Jan-Jonathan: Introduction: Interfaith and Social Movement Theory, in: John Fahy/Jan-Jonathan Bock/Samuel S. Everett (eds.): The Interfaith Movement. Mobilising Religious Diversity in the 21st Century. Abingdon: Routledge, 2019, pp. $1-27$.

Foucault, Michel: The Birth of Biopolitics. Lectures at the College de France 1978-79, translated by G. Burchell. Basingstoke: Palgrave Macmillian, 2008.

Galal, Lise Paulsen: Between Representation and Subjectivity: Interreligious Dialogue in Denmark, in:JRAT 6(2/2020), pp.

Galal, Lise Paulsen/Liebmann Lund, L./Nordin, Magdalena: Routes and Relations in Scandinavian Interfaith Forums: Governance of Religious Diversity by States and Majority Churches, in: Social Compass 65 (3/2018), pp. 329-345. 
Gray, Breda: Catholic Church Civil Society Activism and the Neoliberal Governmental Project of Migrant Integration in Ireland, in:François Gauthier/Tuomas Martikainen (eds.): Religion in the Neoliberal Age. Political Economy and Modes of Governance. Farnham: Ashgate, 2013, pp. 69-9o.

Griera, Maria del Mar/Nagel, Alexander-Kenneth: Interreligious Relations and Governance of Religion in Europe: Introduction, in: Social Compass 65 (3/2018), pp. 301-311.

Ilić, Angela: Looking Through a Veil: Challenges and Perspectives of Interreligious Dialogue in Serbia, in: JRAT 6 (2/2020), pp.

Joy, Morny: Gender and its Vicissitudes, in: Jay Johnston/Kocku von Stuckrad (eds.): Discourse Research and Religion: Disciplinary Use and Interdisciplinary Dialogues. New York, NY/Berlin: de Gruyter, 2020.

Koch, Anne: Competitive Charity. A Neoliberal Culture of 'Giving Back' in Global Yoga, in: Journal of Contemporary Religion 30 (3/2015), pp. 73-85.

Kuppinger, Petra: Faithfully Urban. Pious Muslims in a German City. New York, NY, Oxford: Berghahn, 2015.

Lehmann, Karsten: Interreligious Dialogue - a Response to Processes of Secularization, in:JRAT 6 (2/2020), pp.

Lehmann, Karsten: Religious NGOs in International Relations. The Construction of the 'Religious' and the 'Secular' (Routledge Studies in Religion and Politics). Abingdon, New York, NY: Routledge, 2016.

Lindner, Doris/Lehmann, Karsten: „... wir fingen an, über Religion zu reden.“ Impulse zur Diskussion um Schule unter postsäkularen Bedingungen, in: Manfred Oberlechner,/Franz Gmainer-Pranzl/Anne Koch (eds.): Religion bildet. Diversität, Pluralität, Säkularität in der Wissensgesellschaft. Baden-Baden: Nomos, 2019, pp. 135-148.

Mahmood, Saba: Religious Reason and Secular Affect: An Incommensurable Divide? in: Talal Asad/Wendy Brown/Judith Butler/Saba Mahmood (eds.): Is Critique Secular? Blasphemy, Injury, and Free Speech (The Townsend Papers in the Humanities No. 2). Berkley, CA et al.: University of California Press, 2009, pp. 64-101.

Martikainen, Tuomas: Multilevel and Pluricentric Network Governance of Religion, in: François Gauthier/Tuomas Martikainen (eds.): Religion in the Neoliberal Age. Farnham: Ashgate, 2013, pp. 129-142.

Modood, Tariq: Post-Immigration Cultural Diversity and Integration, in: EU I Working Paper RSCAS 61 (2013), Global Governance Programme-6o, Cultural Pluralism, Retrieved from Cadmus, European University Institute Research Repository, http:// hdl.handle.net/1814/27697 (date of last access: 16.12.2019).

Nagel, Alexander-Kenneth: Enacting Diversity: Boundary Work and Performative Dynamics in Interreligious Activities, in: Giuseppe Giordan/Andrew P. Glynch 
(eds.): Interreligious Dialogue. From Religion to Geopolitics. Annual Review of the Sociology of Religion Vol. 10 (2019), pp. 111-127.

Nagel, Alexander-Kenneth: Empowerment or Oligarchisation? Interfaith Governance of Religious Diversity in Two German Cities, in: John Fahy/Jan-Jonathan Bock (eds.): The Interfaith Movement. Mobilising Religious Diversity in the 21st Century. Abingdon: Routledge, 2019, pp. 104-121.

Prideaux, Melanie: Legitimising Religion in Public: Interreligious Dialogue and the Established Church in England, in: JRAT 6 (2/2020), pp.

Körs, Anna/Nagel, Alexander-Kenneth: Local 'Formulas of Peace': Religious Diversity and State-Interfaith Governance in Germany, in: Social Compass 65 (3/2018), pp. $346-362$.

Schambeck, Mirjam: A Plea for Interreligious Education, at: European Parliament: Expert Report given at Committee on Culture and Education (15.09.2015), https://www.europarl.europa.eu/streaming/?event=20150915-o9oo-committeecult\&language=en, 11:15-29, (date of last access: 16.12.2019).

Schmid, Hansjörg: Interreligious Dialogues in Switzerland: A Multiple-Case Study Focusing on Socio-Political Contexts, in: JRAT 6 (2/2020), pp.

Schuh, Cora/Burchardt, Marian/Wohlrab-Sahr, Monika: Contested Secularities: Religious Minorities and Secular Progressivism in the Netherlands, in: Journal of Religion in Europe 5 (3/2012), pp. 349-383.

Stolz, Jörg/Könemann, Judith: A Theory of Religious-Secular Competition, in: Jörg Stolz/Judith Könemann/Mallory Schenuwly Purdie/Thomas Englberger (eds.): (Un)Belivieving in Modern Society. Farham, Burlington, VT: Ashgate, 2016, pp. 11-50. Zifonun, Darius/Jakisa, Miranda: Religiöse Vielfalt und religiöser Konflikt: der Fall Bosnien und Herzegowina, in: Hans G. Kippenberg/Jörg Rüpke/Kocku von Stuckrad (eds.): Europäische Religionsgeschichte. Ein mehrfacher Pluralismus, Vol I. Göttingen: V\&R, 2009, pp. 411-438. 